\title{
Pengaruh Physical Evidence terhadap Keputusan Pembelian Konsumen di Café Infinito Culinery Bandung
}

\author{
Fenny May Sara ${ }^{1}$,Caria Ningsih ${ }^{1}$, Rini Andari ${ }^{2}$ \\ ${ }^{1}$ Manajemen Industri Katering, Fakultas Pendidikan Ilmu Pengetahuan Sosial, Universitas \\ Pendidikan Indonesia, Jl. Dr. Setiabudhi No. 229, Bandung 40154, Indonesia \\ 2 Manajemen Resort and Leisure, Fakultas Pendidikan Ilmu Pengetahuan Sosial, Universitas \\ Pendidikan Indonesia, Jl. Dr. Setiabudhi No. 229, Bandung 40154, Indonesia
}

* Korespondensi Penulis. E-mail: fennymaysara12@gmail.com

\begin{abstract}
Abstrak
Penelitian ini bertujuan untuk mengetahui pengaruh physical evidence terhadap keputusan pembelian konsumen di Cafe Infinito Culinery. Keputusan pembelian konsumen adalah tahap di mana konsumen membentuk niat untuk membeli produk atau layanan yang paling disukai oleh konsumen (Kotler dan Keller, 2009). Physical evidence adalah desain fasilitas fisik yang menjadi peran utama dalam proses sosialisasi konsep tentang tujuan perusahaan untuk mengkomunikasikan komunikasi dalam norma, nilai, peran, perilaku dan pola hubungan antara karyawan dan konsumen (Tjiptono, 2008). Penelitian ini dilakukan pada konsumen subjek Culinery Infinito Cafe sebanyak 100 responden. Instrumen pengumpulan data yang digunakan berupa kuesioner physical evidence yang terdiri dari fasilitas eksterior (5 item valid), fasilitas interior (10 item valid), fasilitas lain (valid 5 item) dan keputusan pembelian konsumen (9 item valid). Reliabilitas physical evidence kuesioner adalah sebesar 0,945 dan keputusan pembelian konsumen adalah sebesar 0,885. Analisis data yang digunakan dalam penelitian ini adalah dengan menggunakan analisis regresi pada SPSS 22.0. Hasil dari penelitian ini menunjukkan bahwa ada pengaruh antara physical evidence terhadap keputusan pembelian konsumen di Café Infinito Culinery. Pada hasil analisis regresi sederhana, ada pengaruh antara physical evidence, yang terdiri dari beberapa dimensi (fasilitas eksterior, fasilitas interior, dan fasilitas lainnya), terhadap keputusan pembelian konsumen.
\end{abstract}

Kata Kunci: $\quad$ Physical Evidence; Keputusan Pembelian; Konsumen

\section{Pendahuluan}

Pariwisata merupakan suatu kegiatan zaman sekarang yang dilakukan dengan dasar kebutuhan terhadap kesehatan, kenikmatan, dan kesenangan melihat alam semesta. Apabila ditinjau lebih lanjut lagi, pariwisata dapat menumbuhkan pergaulan diantara berbagai bangsa dan kelas dalam kehidupan bermasyarakat. Sehingga pariwisata dapat mempengaruhi perkembangan industri, perniagaan, perdagangan serta transportasi dapat berkembang secara baik Muljadi, (2012:5).

Pariwisata akan berkembang apabila ditunjang dengan sarana objek wisata, travel agent (agen perjalanan), dan restoran. Selain itu, pariwisata akan berkembang apabila ditunjang oleh usaha-usaha kecil yang berkaitan dengan bidang makanan. Berkembanganpesatnya industri pariwisata, bisnis kuliner sudah banyak bermunculan. Terutama di kota Bandung yang terkenal dengan wisata kuliner dan wisata alamnya.

Bisnis kuliner tersebut dapat berupa restoran, kafe, pedagang kaki lima, dan sebagainya. Hal ini adalah bukti berkembangnya usaha jasa boga. Usaha jasa boga telah menjadi salah satu peluang usaha yang menjanjikan bagi pengusaha maupun dunia pariwisata.

Kota Bandung sebagai salah satu kota yang memiliki banyak destinasi wisata, yang merupakan salah satu tujuan wisata favorit di Indonesia. Bandung juga mulai dikenal oleh wisatawan mancanegara. 
Sebagai kota wisata, Bandung memiliki banyak pilihan destinasi kuliner. Destinasi kuliner itu mulai dari yang tradisional, Western,Japanese Food, dan Korean Food. Hal ini bisa dibuktikan dengan semakin banyaknya restoran di kota yang dijuluki Kota Kembang ini.

Restoran, kafe, dan bar merupakan suatu komponen fasilitas pendukung pariwisata yang menunjang pelayanan jasa. Fasilitas ini sangat diperlukan untuk menunjang sarana pariwisata yang lainnya. Kota Bandung memiliki banyak restoran, salah satunya kafe yang sedang penulis teliti yaitu Cafe Infinito Culinery.

Berdasarkan hasil prapenelitian selama tiga tahun terakhir, pendapatan kafe memang tidak terjadi penurunan. Berikut ini adalah data pendapatan selama tiga tahun terakhir:

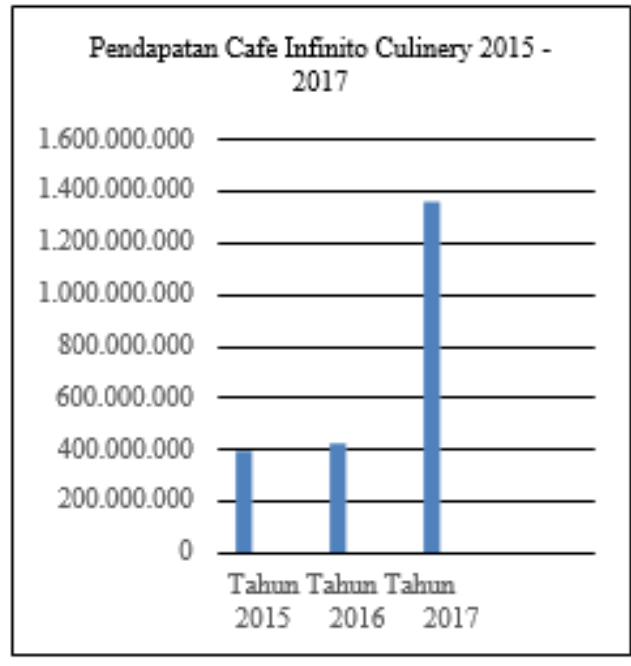

Sumber: Diolah oleh penulis, 2017

Gambar 1. Data Pendapatan Café Infinito Culinery Tahun 2015 - 2017

Dapat dilihat dari gambar 1 bahwa pendapatan yang didapat oleh Cafe Infinito Culinery mengalami kenaikan yang sangat signifikan pada tahun 2017. Hal ini dikarenakan pada awa Januari 2017 Café Infinito berpindah lokasi. Lokasi saat ini berada di Jalan Haji Wasid. Lokasi tersebut berdekatan dengan sekolah, universitas, dan kantor-kantor.

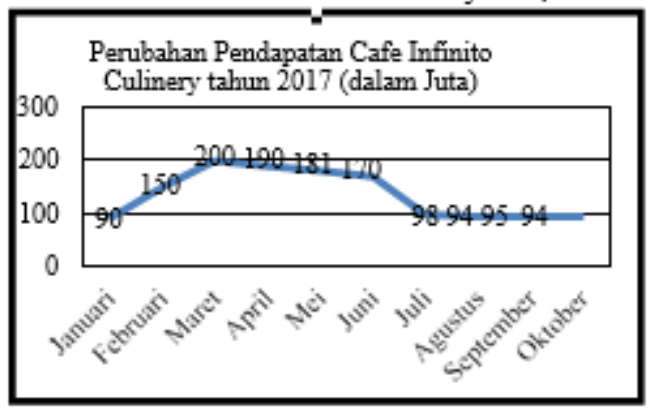

Sumber: Diolah oleh penulis, 2017

Gambar 2. Data Perubahan Pendapatan Café Infinito Culinery Tahun 2017

Berdasarkan Gambar 2 pendapatan Cafe Infinito Culinery mengalami fluktuasi. Selama Januari hingga maret 2017 pendapatan Cafe Infinito Culinery mengalami peningkatan yang cukup stabil. Pendapatan Cafe Infinito Culinery mengalami penurunan pada bulan Maret sebesar 5\% hingga Juli sebesar 4,08\%. Pada bulan September mengalami peningkatan sebesar $1,06 \%$ akan tetapi pada bulan Oktober mengalami penurunan kembali sebesar $1,05 \%$.

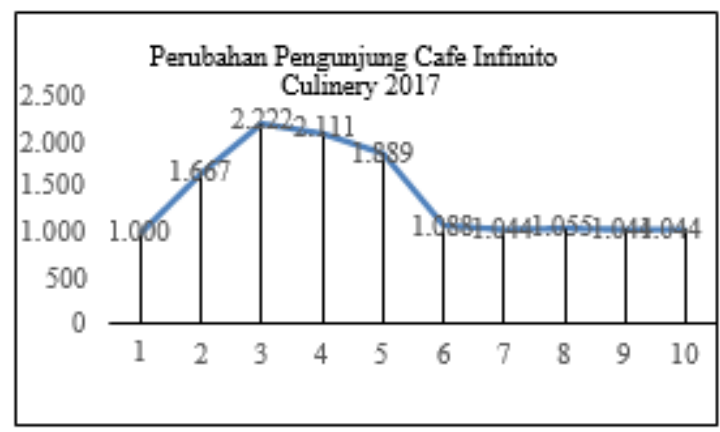

Sumber: Diolah oleh penulis, 2017

Gambar 3. Data Perubahan Pengunjung Café Infinito Culinery Tahun 2017

Pada gambar 3 data pengunjung pada bulan Januari 2017 mengalami kenaikan yang stabil hingga bulan bulan Maret sebanyak 44,5\%. Pada bulan Maret hingga bulan Mei mengalami penurunan jumlah pengunjung sebanyak 24,5\%. Bulan Agustus jumlah pengunjung yang datang ke Cafe Infinito Culinery kembali naik 
sebanyak $1.1 \%$ dan pada bulan September hingga Oktober kembali menurun sebanyak $1,1 \%$.

Selain data-data yang telah didapat dari pihak manajemen Cafe Infinito Culinery dan didapatkan juga dari hasil wawacara yang telah dilakukan dengan pemilik Cafe Infinito Culinery bahwa pada bulan Juni terjadinya penurunan pengunjung. Pada bulan Juni pengunjung setiap harinyahanya memenuhi $40 \%$ seating capacity yang berjumlah 50. Selain diCafe Infinito Culinery terdapat furniture yang kecil, toilet yang sempit, layout cafe (ruangan cafe) yang kecil, dan parkir yang kurang memadai.

Hal ini tentu saja membuat konsumen merasa tidak nyaman dan akhirnya berpengaruh terhadap keputusan pembelian konsumen. Penulis melakukan wawancara kepada beberapa konsumen Cafe Infinito Culinery pada tanggal 20 September 2017. Wawancara dilakukan kepada konsumen Cafe Infinito Culinary penulis mengambil 3 konsumen dari 30 orang yang datang di hari yang berbeda. Penulis akan menjabarkan keluhan kesah konsumen sebagai berikut: Konsumen I menjelaskan bahwa merasa tidak nyaman pada jumlah tempat duduk yang disediakan oleh pihak Cafe Infinito Culinery.

Karena pada siang hari pada saat jam makan siang, kursi yang disediakan sudah penuh sehingga mengharuskan untuk menunggu kursi yang kosong. Pada tanggal

21 September 2017 penulis melakukan wawancara kepada konsumen II. Konsumen II mengeluhkan bahwa fasilitas toilet yang disediakan oleh pihak Cafe sangat tidak nyaman karena toilet yang kurang bersih dan toilet yang disediakan hanya satu untuk penggunaan bersama dengan karyawan. Penggunaan toilet wanita dan pria disamakan, toilet yang kecil, dan juga tidak terawat.

Pada tanggal 22 September 2017 wawancara selanjutnya kepada konsumen

III. Konsumen III mengatakan bahwa parkiran yang disediakan tidak luas sehinggga jika parkiran penuh, maka konsumen harus parkir sedikit jauh dari lokasi Cafe. Kursi yang disediakan juga tidak nyaman dan kecil karena terbuat dari kayu. Apabila konsumen duduk dalam waktu yang lama akan terasa tidak nyaman.

Berdasarkan cuplikan wawancara yang dilakukan oleh penulis terdapat beberapa aspek yang belum optimal. Hal ini tentu akan berpengaruh pada pendapatan dan jumlah pengunjung. Selain itu, hal ini dapat menurunkan keputusan pembelian konsumen. Keputusan pembelian konsumen adalah sebuah penyelesaian masalah pada suatu kegiatan membeli barang atau jasa untuk memenuhi kebutuhan dan keinginan yang terdiri dari pengenalan produk, mengevaluasi alternative pembelian, keputusan pembelian, dan setelah pembelian Swastha, (2007:68).

Kotler dan Keller (2012:170), menyatakan"In the evaluation stage, the consumers from preferences among the brands in the choice set and may also from an intention to buy the most preferred brand"(Pada tahap evaluasi, konsumen memilih antara merek disertai pilihan dan mungkin juga dari niat untuk membeli merek yang paling disukai). Keputusan pembelian konsumen merupakan suatu kegiatan konsumen untuk memilih, menilai, dan mengevaluasi suatu alternatif pembelian sesuai dengan apa yang konsumen perlukan atau inginkan.

Menurut Kotler (2007:223), konsumen memerlukan suatu strategi perilaku kosumen untuk mencapai sasaran tersebut dan terdapat beberapa faktor internal serta eksternal yang turut mempengaruhi. Faktor eksternal yang dimaksud adalah kebudayaan, sosial, pribadi, dan psikologis. Menurut Tjiptono (2007:18), faktor internal terdiri dari 7P yaitu: product, price, place, promotion, people, process, dan physical evidence.

Menurut Kotler dan Armstrong (2014:76), bauran pemasaran serupakan suatu seperangkat alat pemasaran yang digunakan perusahaan untuk mencapai 
tujuan pemasaran di pasar sasarannya. Para pebisnis menggunakan bauran pemasaran untuk mendapatkan tanggapan yang diinginkan oleh perusahaan atas produk yang ditawarkan. Berdasarkan pada penjelasan para ahli diatas tersebut dapat disimpulkan bahwa bauran pemasaran mempengaruhi keputusan pembelian konsumen.

Menurut paparan para ahli yang telah dijelaskan oleh penulis sebelumnya, menyatakan bahwa bauran pemasaran sangat berpengaruh kepada keputusan pembelian konsumen. Menurut Tunggal (2008:28), bauran pemasaran berpengaruh terhadap keputusan pembelian konsumen karena bauran pemasaran merupakan strategi yang digunakan oleh peruhasaan untuk menciptakan pertukaran dalam mencapai tujuan perusahaan. Salah satu bauran pemasaran yang berpenguruh di Cafe Infinito adalah masalah physical evidence, atau yang biasa kita kenal dengan sebutan bukti fisik.

Physical evidence merupakan salah satu bauran pemasaran yang sangat penting bagi keputusan pembelian konsumen. Hal ini merupakan peranan penting dalam menciptakan keputusan pembelian konsumen. Jika keputusan pembelian konsumen di Cafe Infinito Culinery menurun, maka dapat mempengaruhi pendapatan Cafe Infinito Culinery.

Menurut Mary Jo Bitner (2008:71), physical evidence merupakan bentuk penyempaian aspek lingkungan, layanan, dan fasilitas yang diberikan oleh perusahaan kepada konsumen tentang keseluruhan perusahaan tersebut.

Untuk meningkatkan perekonomian di bidang kuliner itu sendiri, diperlukan pengevaluasian terhadap masalah yang membuat pendapatan menurun. Setelah pebisnis kuliner mengetahuinya, maka harus ada pembaharuan yang lebih menarik dari pada sebelumnya. Hal ini bertujuan untuk menaikkan keputusan pembelian konsumen.

Berdasarkan dari data-data yang diberikan oleh pihak manajemen Cafe
Infinito, wawancara kepeda pemiliki Cafe Infinito Culinery, dan hasil wawancara kepada konsumen yang datang ke Cafe Infinito Culinery dapat disimpulkan bahwa ada aspek-aspek yang belum optimal pada physical evidence di Cafe Infinito Culinery dan adanya penurunan jumlah kedatangan pengunjung.

Maka salah satu langkah yang dapat dilakukan dengan melakukan pengelolaan physical evidence. Hal yang dapat dilakukan seperti perbaikan fasilitaseksterior yang bagus dan menarik, perawatan fasilitas interior, fasilitas penunjang seperti kenyamanan area parkir, keamanan, serta kebersihan area sekitar. Physical evidence sangat penting dalam membentuk persepsi konsumen.

Pada physical evidence konsumen dapat mengidentifikasikan dan membandingkan suatu perusahaan jasa dengan perusahaan jasa lainnya. Berdasarkan permasalahan yang terjadi di Cafe Infinito Culinery, maka dari itu penulis tertarik untuk melakukan penelitian tentang "Analisis Pengaruh Physical evidence terhadap Keputusan Pembelian Konsumen di Cafe Infinito Culinery Bandung“.

\subsection{Pariwisata}

Pariwisata merupakan perjalanan yang dilakukan berkali-kali (berputar-putar) dari suatu tempat ke tempat lain yang bertujuan untuk mencari kesenangan dan mendapatkan kepuasan (Irawan, 2010:11). Menurut Demartoto (2014:9), bahwa dalam pariwisata adalah terdapat elemen-elemen yang berkaitan seperti: wisatawan, daerah tujuan wisata, perjalanan, industri, dan lainnya. Perjalanan wisata yang dilakukan ke daerah tujuan wisata bersifat tidak permanen atau hanya sementara.

Pariwisata merupakan suatu gejala ekonomi, yang disebabkan adanya permintaan dari pihak wisatawan atas produk dan berbagai fasilitas yang ditawarkan oleh pihak pemberi jasa (Sinaga, 2010:12). Menurut Pitana dan Diarta (2009:57), pariwisata merupakan suatu 
kegiatan seseorang maupun kelompok untuk melakukan kegiatan berpergian atau keluar dari rumah. Hal ini bertujuan untuk mengunjungi lingkungan yang baru bertujuan untuk tinggal sementara dan melakukan wisata, pengobatan, serta tujuan lainnya.

Ada beberapa komponen pokok yang secara umum disepakati di dalam batasan pariwisata (khususnya pariwisata internasional) menurut Pitana dan Diarta (2009:46), yaitu sebagai berikut:

a. Traveler, yaitu orang yang melakukan perjalanan antar dua atau lebih lokalitas

b. Visitor, yaitu orang yang melakukan perjalanan perjalanan ke daerah yang bukan merupakan tempat tinggalnya, kurang dari 12 bulan, dan tujuan perjalanannya bukanlah untuk mencari nafkah, pendapatan, atau penghidupan di tempat tujuan.

c. Tourist, yaitu bagian dari visitor yang menghabiskan waktu paling tidak satu malam (24 jam) di daerah yang di kunjungi.

\subsection{Restoran}

Restoran Menurut Keputusan Menteri Pariwisata, Pos, dan Telekomunikasi Nomor KM 95/HK. 103/MPPT-87 merupakan usaha jasa boga yang dikelola secara komersial untuk menyediakan makan dan minum. Menurut Hayes dan Ninemeier (2011:98), menyatakan bahwa restoran adalah tempat yang diorganisasi secara komersial, yang menyelenggarakan pelayanan makanan dan minuman dengan baik kepada semua tamunya.

Restoran bertujuan untuk menyajikan makanan dan minuman umumnya pada harga tinggi dengan tingkat pelayanan tinggi. Wiyasha (2011:26), menyatakan restoran merupakan industri jasa pelayanan makanan dan minuman yang dikelola secara komersil serta profesional dengan menyediakan makanan dan minuman yang khas diikuti dengan sistem penyajian yang menarik. Restoran adalah sebuah tempat untuk mencari keuntungan dari penjualan makanan, minuman, dan memberikan kepuasan kepada konsumen yang datang. Tujuan pengoperasian restoran adalah untuk mencari keuntungan, selain tujuannya bisnis dan mencari laba, juga memberikan kepuasan kepada tamu merupakan tujuan utama pada restoran.

\subsection{Konsep Bauran Pemasaran}

Menurut Kotler dan Armstrong (2012:27), pemasaran di dunia industri pariwisata sangat penting karena memberikan kontribusi yang begitu besar dalam mempromosikan atau menawarkan produk dan jasa. Pemasaran merupakan suatu proses untuk perusahaan dalam menciptakan kepada kosumen. Hal ini bertujuan untuk menangkap nilai lebih dan menbangun hubungan yang kuat dengan konsumen.

Kotler dan Armstrong (2012:58) menyatakan bahwa bauran pemasaran adalah "The set of controllable tactical marketing tools-product, price, place, and promotion- that firm blends to produce the response it wants in the target market". Bauran pemasaran adalah seperangkat alat pemasaran mulai dari produk, harga, promosi, dan distribusi, yang dipadukan untuk menghasilkan respon yang diinginkan oleh pasar sasaran. Konsep paling dasar dalam pemasaran adalah bauran pemasaran, yang diidefinisikan sebagai bagian dari kendali perusahaan yang biasa digunakan untuk mengkomunikasikan tujuan perusahaan kepada konsumen.

Menurut Alma (2011:205), bauran pemasaran merupakan kegiatan mencampur kegiatan pemasaran agar mendapatkan hasil kombinasi maksimal sehingga mendatangkan hasil yang bagus dan memuaskan. Alat pemasar (marketing mix) yang dapat digunakan untuk mencapai tujuan pemasaran yang diinginkan dalam segmentasi pasar. Kotler dan Keller (2012:47) mengklasifikasikan bauran pemasaran kedalam empat kelompok yang disebut $4 \mathrm{P}$, yaitu price, place, product, and promotion. 
Sementara itu untuk pemasaran jasa perlu bauran yang diperluas (expanded marketing mix fot services) dengan penambahan unsur people, Physical evidence, dan process (Hurriyati, 2010:48).

Variabel yang merupakan bauran pemasaran (marketing mix):

\section{a. Product}

Product menurut Kotler dan Amstrong (2012:51) merupakan kombinasi barang dan jasa perusahaan yang ditawarkan kepada target pasar.

\section{b. Price}

Price menurut Kotler dan Amstrong (2012:51) adalah jumlah uang pelanggan yang harus dikeluarkan untuk mendapatkan produk.

\section{c. Place}

Place merupakan tempat atau dimana jasa tersebut disediakan. Lokasi yang bagus adalah lokasi yang mudah dicapai tanpa diperlukannya biaya yang besar dan juga waktu yang lama untuk medatanginya. Tempat menurut Kotler dan Amstrong (2012:51) ialah meliputi kegiatan perusahaan dalam membuat produk tersedia untuk target konsumen.

\section{d. Promotion}

Promotion menurut Kotler dan Amstrong (2012:51) merupakan kegiatan mengkomunikasikan produk dan membujuk pelanggan sasaran untuk membelinya.

\section{e. People}

People ialah sumber daya manusia yang perlu dipelihara dan dikembangkan agar dapat mengsukseskan perusahaan. Dalam perusahaan jasa, orang/karyawan merupakan bagian kerja dari sebuah perusahaan yang dapat memberikan pelayanan bagi konsumen.

\section{f. Process}

Process menyangkut dari cara kerja perusahaan dalam memberika pelayanan kepada konsumen dalam penyediaan hidangan. Proses menurut Ratnasari dan Aksa (2011:42) proses dalam bauran pemasaran ini merupakan gabungan semua aktivitas, umunya terdiri dari prosedur, jadwal pekerjaan, mekanisme, dan hal-hal rutin sampai produk jasa dihasilkan dan disampaikan kepada pelanggan.

\section{g. Physical evidence}

Physical evidence atau bukti fisik menurut Ratnasari dan Aksa, (2011:53) adalah satu sifat marketing mix yang tidak tetap dan berubah-ubah. Manajemen pemasaran yang baik memberikan kepuasan untuk konsumen. Perusahaan tidak akan menjual produk yang sembarangan, ia menjual atau membeli produk yang bermutu dalam waktu tepat dan harga yang layak.

\subsection{Konsep Physical Evidence}

Physical evidence (bukti fisik) memberikan kesempatan istimewa kepada perusahaan dalam mengirimkan pesanpesan yang kuat dan konsisten berkenaan dengan apa yang ingin dicapai yang diberikan perusahaan kepada segmen pasar (Fandy, 2008:64). Selain itu physical evidence juga sangat penting dalam membentuk persepsi karena melalui physical evidence konsumen siap untuk mengidentifikasikan dan membandingkan suatu perusahaan jasa dengan perusahaan jasa lainnya.

Physical evidence erat kaitannya dengan dengan gaya tampilan fisik dan elemen pengalaman lain yang ditemukan ketika konsumen menikmati layanan yang diberikan. Menurut Lupiyoadi (2009:5), physical vidence adalah: "The environment in which the service is delivered and where firm and costumer interact and any tangible component that facilitate performance or communication of the service" (Lingkungan di mana layanan akan dikirim dan di mana interaksi perusahaan dan pelanggan dan komponen nyata yang memfasilitasi kinerja atau komunikasi layanan). Physical evidence atau bukti fisik merupakan lingkungan fisik tempat jasa diciptakan dan langsung berinteraksi dengan konsumen.

Menurut Ririn (2011:52), ada dua tipe bukti fisik, yaitu:

a. Essential evidence (bukti penting), merupakan kepuasan-kepuasan yang dibuat oleh pemberi jasa mengenai 
desain layout dari gedung, ruang, dan lain-lain.

b. Peripheral evidence (bukti tambahan), merupakan nilai tambah yang bila berdiri sendiri tidak akan berarti apaapa.

Menurut Tjiptono F. (2008:145), desain physical evidence berperan besar dalam proses sosialisasi dengan bentuk komunikasi yang menyampaikan nilai-nilai, norma, perilaku, peran, dan pola hubungan antar karyawan, serta antara pelanggan dan karyawan. Physical evidence digunakan oleh perusahaan untuk penyedian palayanan jasa yang berbeda bertujuan agar konsumen dapat membedakan perusahaannya dari para pesaing lainnya dan mengkomunikasikan tipe segmen pasar yang dilayani. Physical evidence sangat penting dalam membentuk pengalaman dan presepsi dari konsumen.

Menurut Zeithaml, Bitner and Gremler (2013:278) menyebutkan bahwa dimensi dari bukti fisik terdapat pada tabel di bawah:

Tabel 1. Dimensi Physical Evidence

\begin{tabular}{|c|c|}
\hline \multicolumn{2}{|c|}{ PHYSICAL EVIDENCE } \\
\hline $\begin{array}{cl}\text { Facility } & \text { Exterior } \\
\text { - } & \text { Exterior } \\
& \text { design } \\
\text { - } & \text { Signage } \\
\text { - } & \text { Parking } \\
\text { - } & \text { Landscape } \\
\text { - } & \text { Surounding } \\
& \text { environment } \\
\text { Facility Interior } \\
\text { - } \quad \text { Interior } \\
& \text { design } \\
\text { - } & \text { Equipment } \\
\text { - } & \text { Signage } \\
\text { - } & \text { Layout } \\
\text { - } & \text { Sound/music/ } \\
& \text { scene/lightig }\end{array}$ & $\begin{array}{cl}\text { Other tangibles } \\
\text { - } & \text { Bussines card } \\
\text { - } & \text { Stationery } \\
\text { - } & \text { Billing } \\
& \text { statements } \\
\text { - } & \text { Reports } \\
\text { - } & \text { Employee } \\
& \text { dress } \\
\text { - } & \text { Uniforms }\end{array}$ \\
\hline
\end{tabular}

Sumber: Zeithaml, Bitner, dan Gremler, 2013

Pada tabel 1 di atas dapat dilhat unsurunsur umum Physical evidence. Fasilitas ekterior mencangkup tentang desain eksterior bangunan, papan nama, parkir, dan lingkungan sekitar. Fasilitas interior menjelaskan tentang bagaiman desain interior ruangan, peralatan yang disediakan, tata letak, pecahayaan, dan musik yang diperdengarkan. Sedangkan fasilitas lainnya menjelaskan tentang daftar menu, tagihan, dan seragam.

\subsection{Konsep Keputusan Pembelian Konsumen}

Menurut Kotler dan Armstrong (2012:128) menyatakan bahwa Keputusan Pembelian Konsumen adalah perilaku pembelian konsumen mengacu terhadap perilaku pembelian konsumen akhir, individu dan rumah tangga, yang membeli barang dan jasa untuk konsumsi pribadi. Keputusan pembelian merupakan pemilihan dari dua atau lebih alternatif pilihan dari keputusan pembelian. Berarti bahwa jika seseorang dapat membuat keputusan, haruslah tersedia beberapa alternatif pilihan.

Keputusan untuk membeli dapat mengarah kepada bagaimana macam proses dalam pengambilan keputusan tersebut. Ada beberapa bentuk proses pengambilan keputusan dan dapat digolongkan sebagai berikut:

a. Fully Planned Purchase (pembelian terencana), baik produk dan merek sudah dipilih sebelumnya. Hal ini biasa terjadi ketika keterlibatan dengan produk tinggi (barang otomotif) namun bisa juga terjadi dengan keterlibatan pembelian yang rendah (kebutuhan rumah tangga). Planned purchase dapat dialihkan dengan taktik marketing misalnya pengurangan harga, kupon, atau aktivitas promosi lainnya.

b. Partially Planned Purchase (rencana pembelian), bermaksud untuk membeli produk yang sudah ada tetapi pemilihan merek ditunda sampai saat pembelajaran. Keputusan akhir dapat dipengaruhi oleh diskon harga, atau display produk.

c. Unplanned Purchase (pembelian yang tidak direncanakan), baik produk dan merek dipilih di tempat pembelian. Konsumen sering memanfaatkan katalog dan produk pajangan sebagai pengganti daftar belanja. Dengan kata lain, sebuah pajangan dapat 
mengingatkan sesorang akan kebutuhan dan memicu pembelian.

\subsection{Perilaku Konsumen}

Kotler dan Armstrong (2012:157) "Consumer buyer behavior refers to the buying behavior of final consumers individuals and households that buy goods and services for personal consumption", sebagaimana dapat diartikan bahwa (Perilaku keputusan pembelian konsumen mengacu pada perilaku pembelian konsumen akhir, individual maupun rumah tangga, yang membeli barang dan jasa untuk konsumsi pribadi). Menurut Schiffman dan Kanuk (2008:6) Perilaku konsumen merupakan suatu gambaran dimana seorang individu mengambil keputusan untuk memanfaatkan sumber daya mereka yang tersedia (waktu, uang, usaha).

Menurut Kotler dan Keller (2008:214), perilaku konsumen merupakan suatu kaadaan di mana seseorang, kelompok, dan organisasi memilih, membeli menggunakan dan menempatkan barang, jasa, ide dan pengalaman untuk memuaskan serta memenuhi keinginan dan kebutuhan mereka. Perilaku konsumen merupakan prilaku seseorang saat mendapatkan, mengkonsumsi atau membuang barang atau jasa pada saat proses pembelian.

Menurut Kotler (2008:25), Ada beberapa faktor-faktor yang mempengaruhi perilaku konsumen, yaitu:

a. Faktor kebudayaan, terdiri dari budaya, subbudaya, dan kelas sosial.

b. Faktor sosial, terdiri dari kelompok refrensi, keluarga, peranan, dan status

c. Faktor pribadi, terdiri dari usia dan tahap daur hidup, pekerjaan, keadaan ekonomi, gaya hidup, dan kepribadian 7 konsep diri.

Faktor psikologis, terdiri dari motivasi, persepsi, belajar, serta kepercayaan diri dan sikap.

\section{Metode Penelitian}

\subsection{Objek Penelitian}

Penelitian ini memiliki dua variabel yaitu satu variabel independen dan satu variabel dependen. Variabel independen dalam penelitian ini adalah variabel bebas (variabel $\mathrm{X}$ ) adalah physical evidence meliputi fasilitas interior, fasilitas ekterior, serta fasilitas lainnya. Sedangkan yang menjadi variabel terikat (variabel Y) yaitu keputusan pembelian (Y) dengan indikator pemilihan produk, pemilihan merek, pemilihan penyalur, pemilihan waktu pembelian, pemilihan jumlah pembelian, dan metode pembayaran. Pada penelitian ini, adapun yang menjadi objek penelitian adalah Cafe Infinito Culinery Bandung. Sedangkan yang dijadikan responden adalah konsumen Cafe Infinito Culinery Bandung.

\subsection{Jenis Penelitian}

Penelitian ini dilakukan untuk menggambarkan sebuah objek penelitian dan untuk menguji hubungan antara variabel serta menguji hipotesis. Jenis penelitian yang digunakan dalam penelitian ini adalah metode deskriptif dan verifikatif. Menurut Sugiono (2010:29), bahwa "Penelitian deskriptif ialah penelitian yang dilakukan untuk mengetahui keberadaan variabel mandiri, baik satu variabel atau lebih variabel (variabel yang berdiri sendiri) tanpa adanya membuat perbandingan dan atau mencari hubugan variabel satu sama lain".

Sedangkan metode penelitian verifikatif adalah penelitian yang dilakukan untuk menguji kebenaran suatu hipotesis yang dilaksanakan melalui pengumpulan data di lapangan. Pengujian hipotesis tersebut mengambarkan perhitungan statistik. Sehingga metode penelitian verifikatif dalam penelitian ini bertujuan untuk mengetahui pengaruh dari Physical evidence terhadap Keputusan Pembelian Konsumen di Café Infinito Culinery.

Adapun variabel yang menjadi objek penelitian ini adalah sebagai berikut : 
Tabel 2. Objek Penelitian

\begin{tabular}{lll}
\hline Variabel & \multicolumn{1}{c}{ Sub Variabel } \\
\hline $\begin{array}{c}\text { Physical } \\
\text { evidence }\end{array}$ & $\bullet$ & Fasilitas \\
& & eksterior \\
& • & Fasilitas interior \\
& Fasilitas lainnya \\
\hline Keputusan Pembelian & Pemilihan \\
Konsumen & Produk \\
& Pemilihan \\
& merek \\
& Pemilihan \\
& penyalur \\
& Pemilihan \\
& & waktu \\
& pembelian \\
& Pemilihan \\
& jumlah \\
& pembelian \\
& Metode \\
& & pembayaran \\
\hline Sumber : Diolah oleh penuis. 2019 &
\end{tabular}

Jumlah responden pada penelitian ini adalah sebanyak 100 responden dengan jumlah laki-laki 34 dan perempuan sebanyak 66 orang. Retang usia responden dalam penelitian ini mulai dari usia 20 hingga 40 tahun ke atas. Untuk karakteristik pekerjaan reponden adalah mahasiswa, PNS, karyawan swasta, wiraswasta, dan siswa.

Hipotesis yang diajukan dalam penelitian ini adalah apakah terdapat pengaruh physical evidence terhadap keputusan pembelian konsumen di cafe Infinito Culinery.

Hipotesis tersebut akan diuji dengan menggunakan analisis regresi linear sederhana.

\section{Hasil dan Pembahasan}

\subsection{Tanggapan Responden Mengenai Physical Evidence}

Berikut rekapitulasi tanggapan responden mengenai physical evidence :

Tabel 3. Rekapitulasi Tanggapan Responden Mengenai Physical Evidence

\begin{tabular}{llccc}
\hline No & Sub Variabel & $\begin{array}{l}\text { Total } \\
\text { Skor }\end{array}$ & $\begin{array}{c}\text { Skor } \\
\text { Rata- } \\
\text { rata }\end{array}$ & $\%$ \\
\hline 1 & Fasilitas & 1.913 & 382,2 & 33,97
\end{tabular}

\begin{tabular}{ccccc}
\hline No & Sub Variabel & $\begin{array}{c}\text { Total } \\
\text { Skor }\end{array}$ & $\begin{array}{c}\text { Skor } \\
\text { Rata- } \\
\text { rata }\end{array}$ & $\%$ \\
\hline 2 & $\begin{array}{l}\text { eksterior } \\
\text { Fasilitas } \\
\text { interior }\end{array}$ & 3.636 & 362,6 & 32,23 \\
& $\begin{array}{l}\text { Fasilitas } \\
\text { lainnya }\end{array}$ & 1.901 & 380,2 & 33,80 \\
& Total & 7.458 & 1.125 & 100 \\
\multicolumn{5}{l}{ Sumber : Data diolah penulis, 2017} \\
\end{tabular}

Berdasarkan rekapitulasi hasil tanggapan physical evidence pada tabel 1.3 dapat dilihat bahwa nilai tertinggi dari physical evidence di Cafe Infinito Culinery yaitu pada fasilits eksterior dengan rata-rata skor sebesar 33,97\%. Hal ini dikarenakan tanggapan baik para tamu mengenai fasilitas eksterior yaitu desain bangunan dan kejelasan papan nama. Skor nilai terendah terdapat pada fasilitas interior dengan ratarata skor sebesar 32,23\%. Hal ini dikarenakan hiasan dinding kurang menarik, kesesuaian musik yang tidak sesuai, dan toilet kotor serta tidak nyaman untuk konsumen.

\subsection{Tanggapan Responden Mengenai} Keputusan Pembelian Konsumen

Berikut data rekaptulasi tanggapan responden mengenai kepuasan konsumen:

Tabel 4. Rekapitulasi Tanggapan Responden Mengenai Keputusan Pembelian

\begin{tabular}{|c|c|c|c|c|}
\hline No & $\begin{array}{l}\text { Dimensi } \\
\text { Keputusan } \\
\text { Pembelian } \\
\text { Konsumen }\end{array}$ & $\begin{array}{l}\text { Total } \\
\text { Skor }\end{array}$ & $\begin{array}{l}\text { Skor } \\
\text { Rata- } \\
\text { rata }\end{array}$ & $\%$ \\
\hline 1 & $\begin{array}{l}\text { Pemilihan } \\
\text { Produk }\end{array}$ & 360 & 360 & $\begin{array}{c}19,4 \\
4\end{array}$ \\
\hline 2 & $\begin{array}{l}\text { Pemilihan } \\
\text { merek }\end{array}$ & 290 & 290 & $\begin{array}{c}15,6 \\
6\end{array}$ \\
\hline 3 & $\begin{array}{l}\text { Pemilihan } \\
\text { penyalur }\end{array}$ & 728 & 364 & $\begin{array}{c}19,6 \\
6\end{array}$ \\
\hline 4 & $\begin{array}{l}\text { Pemilihan } \\
\text { waktu } \\
\text { pembelian }\end{array}$ & 705 & 352,5 & $\begin{array}{c}19,0 \\
4\end{array}$ \\
\hline 5 & $\begin{array}{l}\text { Pemilihan } \\
\text { jumlah } \\
\text { pembelian }\end{array}$ & 392 & 392 & $\begin{array}{c}21,1 \\
7\end{array}$ \\
\hline 6 & $\begin{array}{c}\text { Metode } \\
\text { pembayaran }\end{array}$ & 890 & 445 & $\begin{array}{c}24,0 \\
4\end{array}$ \\
\hline
\end{tabular}




\begin{tabular}{clclc}
\hline No & $\begin{array}{l}\text { Dimensi } \\
\text { Keputusan } \\
\text { Pembelian } \\
\text { Konsumen }\end{array}$ & $\begin{array}{l}\text { Total } \\
\text { Skor }\end{array}$ & $\begin{array}{l}\text { Skor } \\
\text { Rata- } \\
\text { rata }\end{array}$ & $\%$ \\
\hline \multicolumn{2}{c}{ Total } & 3365 & 1851 & 100 \\
\hline \multicolumn{2}{l}{ Sumber : Data diolah penulis, 2017} & &
\end{tabular}

Berdasarkan pada tabel 4 rekapitulasi hasil tanggapan responden mengenai keputusan pembelian konsumen dapat dilihat bahwa nilai tertinggi adalah dimesi metode pembayaran sebanyak $24,04 \%$. Hal ini dikarenakan pembayaran secara tunai serta non tunai sangat mudah dan cepat di Cafe Infinito Culinery. Untuk nilai paling rendah adalah dimensi pemilihan merek. Pemilahan merek sangat rendah di Cafe Infintito Culinery dikarenakan pihak hanya menggunakan media sosial (Instagram) saja sebagai alat promosinya.

\subsection{Pengaruh Physical Evidence terhadap} Keputusan Pembelian Konsumen

\subsubsection{Analisis Regresi Sederhana}

Analisis regresi linier sederhana dilakukan untuk mengetahui pengaruh fungsional secara linier antara variabel physical evidence (X) terhadap keputusan pembelian konsumen (Y) di Cafe Infinito Culinery. Berikut hasil analisis perhitungan menggunakan SPSS 22 for windows:

Tabel 5. Analisis Regresi Sederhana

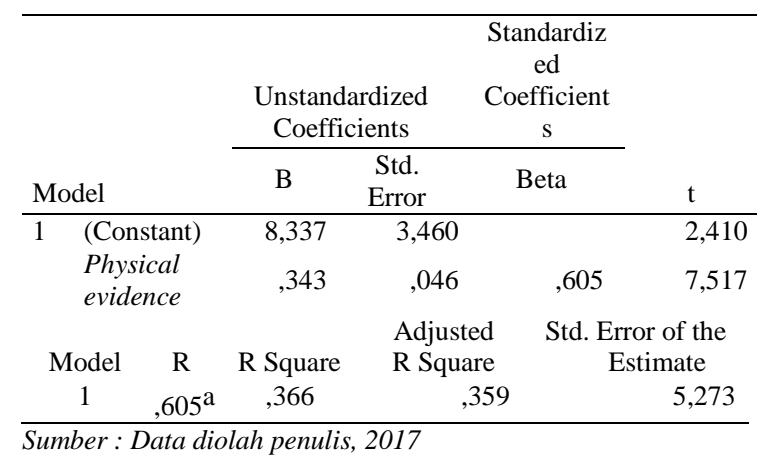

Berdasarkan Tabel di atas 5 hasil uji regresi sederhana pada tabel tampak besar konstibusi variabel physical evidence dapat dilihat dari nilai $\mathrm{R}$ yaitu sebesar 0,605. Ketentuan korelasi ini masuk kedalah katagori kuat. Pengambil keputusan tersebut didapat dari pedoman interpretasi koefisien korelasi nilai r dari Riduwan (2013:136).

$\mathrm{R}$ square digunakan untuk menjelaskan besar pengaruh variabel bebas terhadap variabel terikat (Pallant, 2011). Pada penelitian ini, nilai $\mathrm{R}$ square adalah $36,6 \%$ dengan taraf signifikansi 0,1. Hasil analisis ini dapat diketahui bahwa physical evidence berpengaruh $36,6 \%$ terhadap keputusan pembelian konsumen dan sisanya $63,4 \%$ dipengaruhi oleh faktor lain yang tidak diteliti dalam penelitian ini yaitu product, price, promotion, place, people dan process.

Rumus analisis regresi linear sederhana yaitu:

$\mathrm{Y}=\mathrm{a}+\mathrm{bX}$ Keterangan:

$\mathrm{Y}=$ Variabel terikat $\mathrm{a}=$ Konstanta

$\mathrm{b}=$ Konstribusi besarnya perubahan nilai (X)

$\mathrm{Y}=\mathrm{a}+\mathrm{bX}(8.337+0,343)$

Berdasarkan tabel Coefficients didapat bahwa nilai konstanta adalah 8,337. Hal ini menyatakan bahwa konstanta sebesar 8,377 jika tidak ada nilai physical evidence satu satuan nilai maka keputusan pembelian konsumen 8,337 satu satuan nilai. Koefisien regresi 0,343 satu satuan nilai artinya apabila terjadi peningkatan physical evidence maka keputusan pembelian kosumen akan meningkat 0,343 satu satuan nilai. Sebaliknya apabila terjadi penurunan physical evidence maka akan menurun juga pada keputusan pembelian kosumen sebesar 0,343 satu satuan nilai.

Penelitian ini dilakukan bertujuan untuk mengetahui apakaha ada pengaruh atau tidak antara physical evidence dengan keputusan pembelian konsumen di Café Infinito Culinery menggunakan metode analisis regresi sederhana. Pada pengujian analisis regresi linear sederhana penulis mendapati bahwa pengeruh physical evidence kepada keputusan pembelian konsumen yang terdapat di Cafe Infinito Culinery sebesar $36,6 \%$ dan sisanya $63,4 \%$ dipengaruhi oleh faktor yang tidak diteliti oleh penulis. Pada pengujian analisis regresi sederhana didapat bawah nilai konstanta 
pada 8,337 dan nilai $b$ (nilai perubahan variabel $X)$ sebesar 0,343. Jadi kesimpulannya adalah jika ada perubahan peningkatan pada physical evidence sebesar 0,343 maka pada keputusan pembelian konsumen akan meningkat juga sebesar 0,343 . Hal ini juga berlaku sebaliknya jika ada penurunan pada physical evidence sebesar 0,343 maka keputusan pembelian juga akan menurun sebesar 0,343.

\section{Kesimpulan}

Berdasarkan hasil penelitian diketahui bahwa physical evidence yang dimiliki Cafe Infinito Culinery berada cukup baik. Hal ini ditunjukan dengan jawaban responden terhadap kuisioner variabel physical evidence. Penilaian tertinggi berada pada dimensi fasilitas ekterior. Tanggapan responden mengenai fasilitas ekterior baik hal ini dikarenakan desain bangunan yang ada di Cafe Infinito sangat menarik. Penilaian terendah ada pada dimensi fasilitas interior hal ini dikarenakan desain interior seperti hiasan dinding yang kurang menarik, kesesuaian musik tidak sesuai, serta kondisi toilet yang kurang nyaman.

Keputusan pembelian konsumen Cafe Infinito Culinery pada kategori cukup baik. Skor tertinggi terhadap keputusan pembelian konsumen terdapat dari metode pembayaran. Sedangkan penilaian terendah pada pemilihan merek hal ini dikarenakan pihak Cafe Infinito Culinery hanya lebih aktif pada penggunaan media sosial (instagram) untuk melakukan promosi.

Hasil penelitian ini menemukan bahwa terdapat pengaruh antara physical evidence, yang terdiri dari beberapa dimensi (fasilitas eksterior, fasilita interior, dan fasilitas lainnya), terhadap keputusan pembelian konsumen. Hal ini menunjukan bahwa semakin tinggi dan menarik physical evidencen yang dilakukan oleh Cafe Infinito Culinery makan akan semakin tinggi pula Keputusan Kosumen untuk datang ke Cafe Infinito Culinery.

\section{Daftar Rujukan}

Agung Joko Sulaksono (2011). Pengaruh physical evidence terhadap loyalitas konsumen pada Cafe Rocketz Solo. Solo: Universitas Sebelas Maret Surakarta

Alma, Buchari. (2010). Manajemen Pemasaran dan Pemasaran Jasa. Bandung: Alfabeta.

Anggita Primartiwi. Jazz Terapi Musik untuk Jiwa. Blog Tribunners.[online] Diakses pada tanggal 11 Desember 2017 dari http://www.tribunnews.com/tribunn ers/2015/12/17/jazz-terapi-musikuntuk-jiwa

Arikunto. (2010). Prosedur Penelitian:

Suatu Pendekatan Praktek. Jakata: Rineka Cipta.

Aksa, R. T. (2011). Manajemen Pemasaran Jasa. Bogor: Ghalia Indonesia.

Bitner, Mary Jo. (2008). Services Marketing. New York: McGraw-Hill Education.

Demartoto, Argyo., Soemanto., \& Ariyani, Nur Indah. (2014). Habitus Pengembangan Pariwisata:

Konsep dan Aplikasi. Surakarta: Sebelas Maret University press.

Fennel,D. (1999). Ecotourism An Introduction. New York: Routledge.

Hayes, D. K., \& Ninemeier, J. D. (2011). Restaurant Operations

Management. New Jersey: Pearson Prentice Hall.

Hidayat, B., Triyani, L., \& Hanifa, S. (2009). Peta 100 Tempat Jajan dan Makanan Legendaris di Bandung. Jakarta: Gramedia.

Hurriyati, Ratih. (2010). "Bauran

Pemasaran dan Loyalitas

Konsumen".

Jakarta: Alfabeta CV.

IBM Wiyasha, 2011. F \& B Cost Control untuk Hotel dan Restoran. Yogyakarta: ANDI.

Kampungusaha.com. Cara Efektif Untuk Promosi Rumah Makan. Blog [online]. Diakses 12 Desember 2017 
dari www.bisnismakanan.com/tipspromosi-efektif-untuk-rumahmakan.htm

Kanuk, S. d. (2008). Schiffman dan Kanuk. Jakarta: Indeks.

Kotler, P. (2007). Pemasaran Manajemen. Jakarta: Indeks.

Kotler, Philip dan Kevin Lane Keller, 2008. Manajemen Pemasaran, Jilid 1, Penerbit Erlangga. Jakarta.

Kotler, P., \& Keller. (2012). Marketing Management. Jakarta: Indeks.

Kotler, P., \& Armstrong, G. (2012). Prinsipprinsip Pemasaran. Jakarta: Erlangga.

Kotler, P., \& Armstrong, G. (2014). Principle Of Marketing (15th edition ed.). New Jersey: Pearson Prentice Hall.

Lupiyoadi, R. (2009). Manajemen Pemasaran. Jakarta: SalembaEmpat.

Lovelock, C. D. (2010). Pemasaran Jasa : Manusia, Teknologi, Strategi (7th ed.). Jakarta: Erlangga.

Marsum, A. (2005). Restoran dan Segala Permasalahannya. Yogjakarta:Andi.

Meyers, K. (2009). Panduan Dasar Pelaksanaan Ekowisata. Jakarta: Unesco Office.

Mulyadi, A. J. (2012). Kepariwisataan dan Perjalanan. Jakarta: Raja Grafindo Persada.

Pallant, J. (2011). SPSS Survival Manual: A Step by Step Guide To Data Analysis Unwin.

Peraturan Menteri Pariwisata Dan Ekonomi Kreatif Republik Indonesia Yang Telah Di Atur Pada Nomor 11 Tahun 2014 Tentang Standar Usaha Restoran Di Indonesia. Jakarta: Menteri Pariwisata Dan Ekonomi Kreatif Republik Indonesia.

Pitana, I. G., \& Diarta, I. K. (2009). Pengantar Ilmu Pariwisata. Yogyakarta: Penerbit Andi.

Priyatno, D. (2011). Buku Saku Analisis Statistik Data SPSS. Yogyakarta: Mediakom.

PT. Kreasi Karya Imaji. Mural Cafe dan
Restoran Ciptakan Interior Yang Unik Untuk Menarik Pengunjung. imural.id. [on-line] . Diakses 11 Desember 2017 dari http://www.imural.id/blog/muralcafe/

Ratnasari, R. T., \& Aksa, M. H. (2011). Manajemen Pemasaran Jasa . Bogor: GI.

Riduwan. (2013). Skala Pengukuran Vaiabel-Variabel Penelitian. Bandung: Alfabeta.

Shinta, A. (2011). Manajemen Pemasaran. Malang: STIPER Dharma Wacana Press.

Sinaga, S. (2010). Potensi dan Pengembangan Objek Wisata Di Kabupaten Tapanuli Tengah. Medan: Kertas Karya.

Sangadji, E. d. (2013). Perilaku Konsumen: Pendekatan Praktis Disertai. Yogjakarta: Andi.

Silalahi, U. (2009). Metode Penelitian Sosial. Bandung: Refika Aditama.

Sugiono. (2010). Metode Penelitian Pendidikan Pendekatan Kuantitatif. Bandung: Alfabeta.

Sugiono. (2008). Metode Pemelitian dan Bisnis. Bandung: Alfabeta.

Sugiono. (2011). Metode penelitian kuntitatif kualitatif dan $R \& D$ (14th ed.). Bandung: Alfabeta.

Sugiyono. (2012). Memahami Penelitian Kualitatif. Bandung: Alfabeta.

Sugiyono. (2013). Metode Penelitian Pendidikan (Pendekatan Kuantitatif, Kualitatif, dan R\&D). Bandung: Alfabeta.

Swastha, B. (2007). Manajemen Pemasaran Modern. Yogyakarta: Liberty.

Tjiptono, F. (2014). Pemasaran Jasa. Jakarta: Andi.

Tjiptono, F. (2007). Strategi Pemasaran ( $3^{\text {rd }}$ ed.). Yogyakarta: Andi.

Tinka sabrina (2016). Pengaruh Physical Evidence terhadap Keputusan Pembeian Konsumen (Survey pada Konsumen di Happy Cow Palasari Bandung). Bandung: Universitas 
Pendidikan Indonesia.

Toni Wahid (2013, Juni). Jazz Beat di Cafe.

Diakses pada tanggal 11 Desember 2017 dari

http://www.cikopi.com/2013/06/jaz z-beat-di-cafe/

Tunggal, A. W. (2008). Dasar-Dasar

Customer Relationship

Management (CRM). Jakarta:

Harvindo.

Umar, H. (2008). Metode Penelitian Untuk

Skripsi dan Tesis Bisnis. Jakarta: Rajagrafindo Persada.

Wall, A. M. (1982). Tourism Economics,

Physical, and Social Impacts.

Toronto: Longman Group Limited.

Wijaya, T. (2012). SPSS 20 Untuk Olah dan Interpretasi Data (5th ed.). Yogyakarta: Cahaya Atma Pustaka.

Yazid. (2008). Pemasaran Jasa dan Konsep Implementasi. Jakarta: Ekonisia FE UI.

Zeithaml, V. A., Bitner, M. J., \& Gremler,

A. D. (2008). Services Marketing (5th ed.). Singapore: Mc Graw Hill. 